Supriyadi, H.; Mangunwiryo, H.; Maryono dan Effendi, J.

\title{
PENCEGAHAN PENYAKIT BAKTERIAL PADA IKAN GURAME DENGAN CARA VAKSINASI
}

\author{
Hambali Supriyadi"), Hariyadi Mangunwiryo"*), \\ Maryono ${ }^{* *}$ ) dan Johan Effendi**4)
}

\begin{abstract}
ABSTRAK
Maksud penelitian ini adalah untuk mengetahui jenis bakteri penyebab penyakit pada ikan gurame serta kemungkinan untuk pencegahan penyakit tersebut dengan menggunakan vaksin.

Isolat diambil dari luka dan ginjal ikan gurame yang sakit. Identifikasi dilakukan dengan metode biokimia, sedangkan karakterisasi dilakukan terhadap karakteristik morfologi, biokimia dan fisika. Uji karakterisasi dilakukan terhadap 28 karakter untuk Enterobacter sp. dan 30 karakter untuk Aeromonas bydropbila. Patogenitas isolat terisolasi diuji pada ikan gurame. Uji efektivitas vaksin dari bakteri terisolasi dilakukan pada ikan gurame.
\end{abstract}

Hasil percobaan menunjukkan bahwa ada 2 jenis bakteri penyebab penyakit pada ikan gurame yaitu Enterobacter sp. dan Aeromonas bydrophila. Kedua jenis bakteri tersebut ternyata bersifat patogen. Enterobacter sp. dapat menyebabkan kematian sebesar $100 \%$ dan Aeromonas bydrophila $85 \%$ pada ikan gurame. Vaksin yang dibuat dari kedua jenis bakteri tersebut dapat menimbulkan respon kebal pada ikan gurame.

ABSTRACT: Prevention of Bacterial Diseases in Giant Gouramy by Means of Vaccination, by: Hambali Sxpriyadi, Haryadi Mangwwiryo, Maryowo and Joban Effendi.

The aims of this study is to investigate the species of bacteria causing giant gouramy (Ospbronemus gouramy) disease. The possible utilization of vaccine produced from isolated bacteria as a prevention method of bacterial fish diseases was also conducted.

Isolates of bacteria were taken from the ulcer and kidney of infected fish. Identification of isolated bacteria was done using biochemical method. Morphological, biochemicals and physical characterization were also made. Twenty eight characters for Enterobacter sp. and 30 characters for Aeromonas bydrophila were studied. Pathogenicities of both bacteria on giant gouramy have also been tested. The evaluation on the effectiveness of vaccine produced from both bacteria to prevent the bacterial diseases on giant gouramy was carried out.

Result of this study indicated that Enterobacter sp. and Aeromonas bydropbila were the disease causing bacteria on gouramy. Enterobacter sp. and Aeromonas bydropbila have caused $100 \%$ and $85 \%$ mortalities of giant gouramy respectivelly. While the mortality of control only $\mathbf{4 5 \%}$. Study on the effectiveness of Enterobacter and Aeromonas vaccines indicated that both vaccines generated immune response on giant gouramy.

KEYWORDS: Bacterial diseases, vaccination, giant gouramy

") Peneliti pada Balai Penelitian Perikanan Air Tawar, Sukamandi

-4) Peneliti pada Pusat Penelitian dan Pengembangan Perikanan, Jakarta

**4) Litkayasa pada Balai Penelitian Perikanan Air Tawar, Sukamandi 


\section{PENDAHULUAN}

Ikan gurame (Ospbronemus gouramy) merupakan salah satu jenis ikan yang mempunyai nilai ekonomis yang tinggi. Namun demikian tingkat pengusahaan ikan oleh petani masih dalam tingkatan atau cara-cara tradisional dengan kepadatan yang rendah dan pemberian pakan yang sederhana yaitu antara lain dari daun-daunan dan limbah rumah tangga, sehingga produktivitasnya sangat rendah. Rendahnya produksi ikan gurame ini dapat dilihat dari data statistik perikanan Direktorat Jenderal Perikanan (1989) bahwa peningkatan penambahan produksi tahun 1984 sampai 1989 hanya tercapai 4,354 ton. Angka tersebut jauh lebih rendah apabila dibandingkan dengan produksi ikan mas yang mencapai 81,137 ton dan ikan tilapia 20,561 ton.

Untuk peningkatan produksi ikan gurame perlu adanya perubahan pola pengusahaannya yaitu menjadi pola pengusahaan secara intensif. Hasil penelitian Suhenda et al. (1990) menunjukkan bahwa ikan gurame dapat dibudidayakan secara intensif di dalam karamba jaring apung dengan pemberian pakan yang memadai, baik kualitas maupun kuantitasnya.

Tersedianya benih yang unggul yaitu yang memiliki sifat selain tumbuh cepat juga tahan terhadap penyakit dan perubahan lingkungan akan sangat mendukung pada usaha peningkatan produksi. Usaha penyediaan benih yang tahan terhadap penyakit dapat diusahakan selain melalui pemberian pakan yang baik juga dapat dilakukan dengan cara menumbuhkan kekebalan yaitu antara lain dengan vaksinasi. Vaksinasi untuk mencegah penyakit bakterial A.bydrophilla pada ikan mas dan ikan lele telah dapat meningkatkan daya kelangsungan hidupnya (Supriyadi dan Widagdo, 1986; Supriyadi, 1988).

Dalam tulisan ini dikemukakan hasil uji efektivitas vaksin yang dibuat dari bakteri A.bydrophilla yang diisolasi dari ikan gurame yang sakit terhadap penyakit bakterial pada ikan gurame baik uji tahap laboratorium maupun uji lapang.

\section{BAHAN DAN METODE}

\section{Isolasi, Identifikasi dan Karakterisasi}

Isolasi bakteri penyebab penyakit dilakukan dari ikan gurame yang sakit. Isolasi diambil dari luka dan dari ginjal ikan gurame yang sakit. Isolat kemudian ditanamkan di atas media TSA (Difco) dan kemudian diidentifikasi dengan metode biokimia (Cowan, 1974; Amos, 1985; Popoff and Veron, 1976). Uji karakterisasi dilakukan terhadap karakteristik morphologi, biokimia dan fisika dari isolat yang diperoleh. 
Supriyadi, H.; Mangunwiryo, H.; Maryono dan Effendi, $J$.

\section{Uji Patogenitas Balteri}

Uji patogenitas atau uji voch postulat dilakukan menggunakan dua isolat bakteri yang berhasil diisolasi dari ikan gurame sakit yaitu Aeromonas bydrophilla dan Enterobacter sp. terhadap benih ikan gurame sehat dengan panjang rata-rata $8,7 \pm 0,7 \mathrm{~cm}$ dan bobot rata-rata $12,4 \pm 2,4 \mathrm{~g}$. Enam kelompok ikan gurame digunakan, 2 kelompok disuntik dengan A.bydropbilla, 2 kelompok dengan Enterobacter masing-masing dengan dosis $10^{8} \mathrm{cfu} / \mathrm{ml}$, sedangkan 2 kelompok lagi disuntik dengan saline sebagai kontrol. Pengamatan dilakukan terhadap kelangsungan hidup ikan uji selama 10 hari dari mulai infeksi.

\section{Uji Effeltivitas Vaksin}

Ikan uji dengan panjang rata-rata $8,7 \pm 0,7 \mathrm{~cm}$ dan bobot $12,4 \pm 2,4 \mathrm{~g}$ divaksin dengan vaksin A.bydrophila dan Enterobacter sp. dengan dosis vaksin masingmasing $10^{5}, 10^{7}$ dan $10^{9} \mathrm{cell} / \mathrm{ml}$. Masing-masing perlakuan dilakukan menggunakan tiga kelompok ikan gurame (masing-masing kelompok terdiri dari 20 ekor ikan) sehingga jumlah ikan yang digunakan 2 (jenis vaksin) x 3 (ulangan) x 4 (perlakuan) x 20 ekor $=480$ ekor. Ikan uji dipelihara dalam jaring yang berukuran $0,5 \times 1 \mathrm{~m}$ dengan ketinggian air $40 \mathrm{~cm}$. Pengamatan dilakukan terhadap kelangsungan hidup ikan, baik setelah divaksin maupun setelah diinfeksi bakteri patogen (uji tantang).

\section{Uji Lapang}

Uji lapang vaksin dilaksanakan di dua lokasi yaitu di kolam percobaan Sukamandi dan di Balai Benih Ikan Sentral Ngrajeg, Magelang, Jawa Tengah.

\section{Uji lapang di Sukamandi}

Ikan uji adalah ikan gurame dengan panjang rata-rata $8,7 \pm 0,7 \mathrm{~cm}$ dan bobot rata-rata $12,4 \pm 2,4 \mathrm{~g}$. Dua belas kelompok ikan uji (masing-masing kelompok terdiri dari 100 ekor) diperlakukan dengan vaksin Enterobacter (3 kelompok), vaksin Aeromonas (3 kelompok), vaksin Aeromonas strain 26 (3 kelompok), dan kontrol ( 3 kelompok). Vaksin diaplikasikan dengan cara perendaman pada dosis $10^{7} \mathrm{sel} / \mathrm{ml}$ selama 30 menit. Kolam yang dipakai adalah kolam tanah dengan ukuran $25 \mathrm{~m}^{2}$ sebanyak 12 buah.

Pengamatan dilakukan terhadap kelangsungan hidup ikan baik pada 1 bulan setelah divaksin maupun setelah uji tantang dengan bakteri patogen. 


\section{b. Ufi lapang di Ngrajeg}

Ikan uji yang dipakai adalah ikan gurame yang berasal dari Banjarnegara dengan panjang rata-rata $8,52 \mathrm{~cm}$ dan bobot rata-rata $9,5 \mathrm{~g}$. Dua belas kelompok ikan uji masing-masing kelompok terdiri dari 75 ekor diperlakukan dengan vaksin Enterobacter (3 kelompok), vaksin Aeromonas (3 kelompok), antibiotika Tetracyclin (3 kelompok), dan 3 kelompok lagi sebagai kontrol, tidak diberi perlakuan. Vaksin diaplikasikan dengan cara perendaman selama 30 menit pada dosis $10^{7} \mathrm{sel} / \mathrm{ml}$ sedangkan untuk antibiotika digunakan dosis 10 ppm.

Ikan kemudian ditempatkan dalam kolam tanah berukuran $50 \mathrm{~m}^{2}$. Pengamatan dilakukan terhadap kelangsungan hidup ikan pada satu bulan setelah divaksin dan setelah diuji tantang.

\section{HASIL DAN PEMBAHASAN}

\section{Isolasi, Identifikasi dan Karakterisasi}

Hasil isolasi, identifikasi dan karakterisasi bakteri dari ikan gurame yang sakit baik yang berasal dari luka maupun dari ginjal menunjukkan bahwa ada 2 spesies bakteri yang dominan yaitu Enterobacter sp. dan Aeromonas bydrophila.

Hasil isolasi, identifikasi dan karakterisasi menunjukkan bahwa isolat yang diisolasi dari ikan gurame yang sakit didapat 4 isolat Enterobacter sp. (2 isolat berasal dari luka, 2 isolat dari ginjal), dan 6 isolat Aeromonas bydrophila yang terdiri dari 3 isolat berasal dari luka, 3 isolat dari ginjal. Setelah diuji sifat-sifat biokimianya yang meliputi 28 karakteristik untuk Enterobacter sp. dan 30 karakteristik untuk Aeromonas bydrophila (Appendix 1), ternyata menunjukkan bahwa isolat Enterobacter sp. baik yang berasal dari luka maupun dari ginjal mempunyai sifat yang sama. Demikian pula dengan isolat Aeromonas bydrophila ternyata mempunyai sifat yang sama terhadap 30 karakter yang diuji. Hal ini menunjukkan bahwa baik isolat Enterobacter sp. maupun Aeromonas bydro-phila berasal dari strain yang sama.

\section{Uji Patogenitas Bakteri}

Uji patogenitas dilakukan terhadap bakteri Enterobacter sp. dan Aeromonas bydropbila yang berasal dari ginjal masing-masing 1 isolat. Hal ini didasarkan karena baik Enterobacter sp. maupun Aeromonas bydrophila mempunyai sifat yang sama. Uji patogenitas ternyata menunjukkan bahwa kedua jenis bakteri tersebut patogen terhadap ikan gurame. Aeromonas bydropbila ternyata dapat menyebabkan kematian ikan uji sebesar $85 \%$, Enterobacter sp. menyebabkan 
Supriyadi, H.; Mangunwiryo, H.; Maryono dan Effendi, J.

kematian sebesar $100 \%$, sedangkan kematian ikan kontrol hanya $45 \%$.Kematian pada kontrol memang relatif tinggi dari yang diharapkan, hal ini mungkin karena adanya salin yang kurang steril.

\section{Uji Efektivitas Vaksin}

Hasil uji efektivitas vaksin terhadap derajat kelangsungan hidup ikan uji baik setelah vaksinasi maupun setelah uji tantang dapat dilihat pada Table 1.

Table 1. Survival (\%) of fish vaccinated with Enterobacter and Aeromonas vaccines before and after cballenge

\begin{tabular}{lccc}
\hline Vaccines & $\begin{array}{c}\text { Dose } \\
\text { (cell/ml) }\end{array}$ & \multicolumn{2}{c}{ Survival of fisb (\%) } \\
\cline { 3 - 4 } & & Before cballenge & After cballenge \\
\hline Enterobacter & $10^{5}$ & $93,33^{a} \pm 6,33$ & $93,33^{b} \pm 5,45$ \\
& $10^{7}$ & $83,33^{a} \pm 14,34$ & $95,55^{b} \pm 3,14$ \\
Aeromonas & $10^{9}$ & $85,00^{a} \pm 7,07$ & $95,55^{b} \pm 3,14$ \\
& $10^{5}$ & $98,33^{a} \pm 2,36$ & $93,33^{b} \pm 0,00$ \\
Control & $10^{7}$ & $98,33^{a} \pm 2,36$ & $95,55^{b} \pm 3,14$ \\
& $10^{9}$ & $86,67^{a} \pm 15,46$ & $100,00^{b} \pm 0,00$ \\
& & $98,33^{a} \pm 2,36$ & $31,11^{c} \pm 3,14$
\end{tabular}

Remark: Means value with different sign character in eah column indicates significant difference in $5 \%$ confident limits

Baik Aeromonas bydropbila maupun Enterobacter sp. bersifat antigenik, artinya kedua bakteri tersebut dapat menimbulkan respon kebal pada ikan gurame. Pengaruh vaksin dapat dilihat terutama setelah uji tantang yaitu dengan menunjukkan daya kelangsungan hidup yang dihasilkan cukup tinggi yaitu untuk vaksin Enterobacter berkisar antara 93,33\%-95,55\%, sedangkan untuk vaksin Aeromonas berkisar antara 93,33\%-100\%, dibandingkan dengan kontrol yang hanya $31,11 \%$ (Table 1). Hal ini sesuai dengan hasil penelitian Taufik (1994) (in press) yang menunjukkan bahwa vaksin Aeromonas strain 26 telah dapat menimbulkan respon kebal pada ikan gurame. Kualitas vaksin juga ternyata cukup bagus, ditunjukkan oleh hasil sebelum uji tantang di mana daya kelangsungan hidupnya yang tinggi dan tidak berbeda nyata antara kontrol dengan perlakuan. Hal ini menunjukkan bahwa tidak ada sifat toksik dari vaksin tersebut, dan selain itu juga menunjukkan bahwa vaksin tersebut steril artinya tidak terkontaminasi oleh bakteri yang dapat menimbulkan kerusakan pada vaksin. 
Proteksi yang tinggi yang dihasilkan oleh kedua jenis vaksin ini merupakan suatu hal yang sangat menguntungkan dalam strategi penanggulangan penyakit bakterial pada ikan gurame dengan cara pencegahan.

\section{Uji Lapang}

Hasil uji lapang aplikasi vaksin Aeromonas dan Enterobacter terhadap kelangsungan hidup ikan gurame di Sukamandi dapat dilihat pada Table 2. Sedangkan hasil uji vaksin pada ikan gurame di Ngrajeg dapat dilihat pada Table 3.

Table 2. Survival of fish (\%) vaccinated with Enterobacter and Aeromonas vaccines dose $10^{7} \mathrm{cells} / \mathrm{ml}$ before and after challenge

\begin{tabular}{lcc}
\hline \multicolumn{1}{c}{ Vaccines } & \multicolumn{2}{c}{ Survival of treated fisb (\%) } \\
\cline { 2 - 3 } & Before cballenge & After cballenge \\
\hline Enterobacter & $93.66^{a} \pm 4.92$ & $97.53^{b} \pm 1.76$ \\
Aeromonas & $75.33^{a} \pm 20.42$ & $94.23^{b} \pm 4.11$ \\
Aeromonas strain 26 & $88.33^{a} \pm 10.78$ & $91.70^{b} \pm 2.97$ \\
Control & $84.33^{a} \pm 9.81$ & $97.00^{b} \pm 3.30$ \\
\hline
\end{tabular}
Remark: Means value with the same character in each column indicates no significant differences in $5 \%$ confident
limits.

Pada uji lapang dari kedua jenis vaksin baik yang dilaksanakan di Sukamandi maupun yang dilaksanakan di Ngrajeg sebelum uji tantang menunjukkan daya kelangsungan hidup yang tinggi, baik bagi ikan-ikan yang diperlakukan dengan vaksin maupun yang tidak diperlakukan dengan vaksin (kontrol). Hal demikian menunjukkan tidak ada pengaruh negatif (efek racun) dari vaksin tersebut dan tidak menunjukkan adanya kontaminasi atas vaksin yang dipakai. Jadi vaksin tersebut cukup aman.

Daya kelangsungan hidup ikan uji setelah diuji tantang baik memakai vaksin Enterobacter maupun Aeromonas cukup tinggi seperti yang terlihat pada Table 2 dan Table 3. Namun demikian hal ini tidak berbeda nyata dengan kontrol. Hal ini terjadi karena tidak efektifnya uji tantang artinya bakteri yang diinfeksikan pada ikan uji tidak dapat menimbulkan infeksi yang dapat menimbulkan kematian ikan uji. Kelihatannya bakteri tersebut sudah hilang sifat patogenitasnya sehingga tidak dapat menginfeksi ikan uji, atau mungkin 
Supriyadi, H.; Mangunwiryo, H.; Maryono dan Effendi, J.

juga dosis bakteri yang dipakai untuk uji tantang harus ditingkatkan lagi karena kondisi di lapangan mungkin tidak sama dengan kondisi di laboratorium.

Table 3. Survival of fish (\%) treated with vaccines (Enterobacter and Aeromonas) dose $10^{7}$ cells $/ \mathrm{ml}$, and antibiotic (Oxytetracycline $\mathrm{HCl}$ ) 10 ppm, before and after challenge

\begin{tabular}{lcc}
\hline \multicolumn{1}{c}{ Vaccines } & \multicolumn{2}{c}{ Survival of treated fisb (\%) } \\
\cline { 2 - 3 } & Before cballenge & After cballenge \\
\hline Enterobacter & $97.77^{a} \pm 1.66$ & $99.53^{b} \pm 0.66$ \\
Aeromonas & $100.00^{a} \pm 0.00$ & $97.78^{b} \pm 2.26$ \\
Tetracyclin & $97.77^{a} \pm 1.66$ & $97.72^{b} \pm 0.63$ \\
Control & $96.00^{a} \pm 1.08$ & $93.73^{b} \pm 6.88$ \\
\hline
\end{tabular}

Remark: Means value with the same character indicates no significant differences in $5 \%$ confident limits.

\section{KESIMPULAN}

1. Berdasarkan atas hasil percobaan tersebut dapat diambil kesimpulan bahwa Enterobacter sp. dan Aeromonas bydrophila merupakan bakteri yang patogen terhadap ikan gurame.

2. Berdasarkan uji laboratorium ternyata vaksin yang berasal dari kedua jenis bakteri tersebut cukup efektif untuk pencegahan penyakit pada ikan gurame yang disebabkan oleh kedua jenis bakteri.

\section{SARAN DAN RENCANA TINDAK LANJUTT}

Penelitian lanjutan mengenai produksi massal kedua jenis vaksin, dan uji multi lokasi dari kedua vaksin tersebut perlu dilaksanakan.

\section{DAFTAR PUSTAKA}

Amos, K.H. 1985. Procedure for detection and identification of certain fish pathogen. Fish Health section, American Fisheries Society. Corvallis, Oregon. pp. 114.

Cowan, S.T. 1974. Manual for the identification of medical bacteria. Cambridge University Press.pp.238. 
Direktorat Jenderal Perikanan. 1989. Statistik Perikanan Indonesia 1989. Departemen Pertanian. Jakarta.

Suhenda, N., M. F. Sukadi., E.S. Kartamiharja., R. Utami., D. Sadili., M. Sulhi dan A. Hardjamulia. 1991. Pengaruh tipe pakan dan padat penebaran terhadap pertumbuhan ikan gurame (Osphronemus gouramy) Bul. Penel. Perik. Darat Edisi khusus No.3 : 19-36.

Supriyadi, H. dan Jatiwidagdo. 1986. Vaksinasi pada ikan lele (Clarias batracbus) dengan cara injeksi. Bul. Penel. Perik. Darat. 5(2) : 7-9.

Supriyadi, H. 1988. Vaksinasi ikan benih ikan lele (Clarias batrachus) dengan cara perendaman. Bul. Penel. Perik. Darat. 7(1) : 29-32.

Popoff, $M$ and Veron. 1976. A taxonomic study of Aeromonas bydrophilaAeromonas punctata Group. J. Gen. Microbiol. 94 : 11-22. 
Supriyadi, H.; Mangunwiryo, H.; Maryono dan Effendi, $J$.

Appendix 1.

Morpbological, pbysical and biocbemical cbaracteristic of
bacteria Aeromonas bydropbila and Enterobakter sp.

\begin{tabular}{|c|c|c|c|}
\hline \multirow{2}{*}{ No. } & \multirow{2}{*}{$\begin{array}{l}\text { Morpbological, pbysical } \\
\text { and biocbemical test }\end{array}$} & \multicolumn{2}{|c|}{ cbaracteristic of bacteria } \\
\hline & & A. bydropbila & Enterobacter sp. \\
\hline 1. & Shape & rod & rod \\
\hline 2. & Gram reaction & negative & negative \\
\hline 3. & Mortility & motile & motile \\
\hline 4. & Cytochrome oxidase & positive & negative \\
\hline 5. & Catalase & positive & positive \\
\hline 6. & $O / F$ & fermentative & fermentative \\
\hline 7. & Acid from glucose & positive & positive \\
\hline 8. & Gas from glucose & positive & positive \\
\hline 9. & Novobiocin & negative & not done \\
\hline 10. & $R-S$ & ycym & not done \\
\hline 11. & Inositol metabolism & negative & positive \\
\hline 12. & Dulsitol metabolism & positive & positive \\
\hline 13. & Arabinose metabolism & negative & positive \\
\hline 14. & Manitol metabolism & positive & positive \\
\hline 15. & Lactose metabolism & positive & positive \\
\hline 16. & Growth on KCN media & growth & positive \\
\hline 17. & $\mathrm{H}_{2} \mathrm{~S}$ production & negative & negative \\
\hline 18. & Indol production & positive & negative \\
\hline 19. & $T S I A$ & $A / A$ & $K / A$ \\
\hline 20. & Chitine metabolism & negative & negative \\
\hline 21. & Gelatine metabolism & positive & positive \\
\hline 22. & Casein metabolism & positive & negative \\
\hline 23. & Citrat metabolism & positive & positive \\
\hline 24. & Sucrose metabolism & positive & positive \\
\hline 25. & Urease production & negative & negative \\
\hline 26. & $V-P$ & positive & positive \\
\hline 27. & Lysine decarboxylase & negative & positive \\
\hline 28. & Arginine decarboxylase & positive & negative \\
\hline 29. & Ornitbine decarboxylase & negative & positive \\
\hline 30. & Growtb on $\mathrm{NaCl} 2 \%$ & positive & negative \\
\hline
\end{tabular}

Note: $y c y m=$ yellow colony, yellow medium

$A / A=$ Acid slope, acid base

$K / A=$ Alkaline slope, acid base 